\title{
HARTE DAN TUNGGUAN: REDEFINISI ADAT TUNGGU TUBANG PADA KOMUNITAS SEMENDE MIGRAN
}

\author{
HARTE AND TUNGGUAN: \\ REDEFINITION OF TUNGGU TUBANG TRADITION ON \\ MIGRANT SEMENDE COMMUNITY
}

\author{
Zainal Arifin; Maskota Delfi; Sidarta Pujiraharjo \\ Jurusan Antropologi, FISIP, Universitas Andalas \\ Email : arifinzed@gmail.com
}

\begin{abstract}
Semende community at Muara Sahung (Bengkulu) is an ethnic group who migrated from Semende origin (Muara Enim) in South Sumatra Province. This Semende community coexist with various communities with a strong patrilineal culture value, where inheritance of property prefers men. In contrast, Semende cultural, with tunggu tubang customary, women (especially the eldest daughter) are important public figures and preferably as a ruler, and guards who utilize the inheritance from her parents. This article aims to describe the process of redefining the tunggu tubang custom by the Semende community in Muara Sahung, as a result of the strong cultural intervention of the surrounding communities. This article was written from the results of qualitative research approach with data collection techniques, namely in-depth interviews and participatory observation. The results showed that the tunggu tubang custom was an important identity for the Semende migrant community in Muara Sahung, so it needed to be maintained. However, the strong cultural intervention of the surrounding community, has made the tunggu tubang custom redefined. The process of redefinition was done by the conceptualization of inheritance against itself, so that it gave birth to the concept of tungguan (usually in the form of a house), and harte (usually in the form of land). The conceptualization of this custom eventually also carried consequences that possession of tungguan was preferably given to the women (tunggu tubang), while harte were handed to men (jenang).
\end{abstract}

Key words: tunggu tubang, jenang, redefinition, power, possesion

\begin{abstract}
ABSTRAK
Komunitas Semende Muara Sahung di Provinsi Bengkulu adalah sebuah kelompok etnis Semende yang bermigrasi dari daerah asal (Muara Enim) di Provinsi Sumatra Selatan. Komunitas Semende ini hidup berdampingan dengan berbagai komunitas yang memiliki nilai budaya patrilineal yang kuat, di mana pewarisan harta lebih mengutamakan laki-laki. Berbeda dengan budaya Semende, dengan adat tunggu tubang nya, perempuan lah (khususnya anak perempuan tertua) yang dianggap penting dan diutamakan sebagai penguasa, penjaga, dan yang memanfaatkan harta warisan orang tuanya. Artikel ini bertujuan untuk menggambarkan proses redefenisi adat tunggu tubang yang dilakukan komunitas Semende di Muara Sahung, sebagai akibat kuatnya intervensi budaya komunitas di sekitarnya. Upaya memahami realitas ini dilakukan melalui pendekatan penelitian kualitatif dengan teknik pengumpulan data melalui wawancara mendalam dan observasi partisipasi. Hasil penelitian menunjukkan bahwa adat tunggu tubang adalah sebuah identitas penting bagi komunitas migran Semende di Muara Sahung sehingga perlu tetap dipertahankan. Akan tetapi, karena kuatnya intervensi budaya dari komunitas di sekitarnya membuat adat tunggu tubang mengalami proses redefinisi. Proses redefinisi dilakukan dengan cara melakukan konseptualisasi terhadap harta warisan itu sendiri, yang kemudian melahirkan konsep tungguan (biasanya dalam bentuk rumah), dan harte (biasanya dalam bentuk lahan). Konseptualisasi adat ini akhirnya juga membawa konsekuensi di mana penguasaan terhadap tungguan lebih diserahkan kepada perempuan (tunggu tubang), sementara penguasaan terhadap harte diserahkan kepada laki-laki (jenang).
\end{abstract}

Kata kunci: tunggu tubang, jenang, redefenisi, kekuasaan, penguasaan 


\section{PENGANTAR}

Orang Semende (dalam beberapa literatur disebut juga Semendo), adalah salah satu suku bangsa yang wilayah adatnya berada di Kabupaten Muara Enim, Provinsi Sumatra Selatan. Mitologi Semende mengatakan bahwa mereka berasal dari sebaran salah satu kelompok Basemah yang ada di Kabupaten Lahat, Provinsi Sumatra Selatan (Iskandar, 2003), yang dalam perkembangan kemudian juga akhirnya mendapat pengaruh dari Kesultanan Palembang. ${ }^{1}$ Menurut Moyer (1984) komunitas Semende termasuk komunitas yang suka melakukan migrasi sehingga keberadaan mereka juga banyak ditemukan di berbagai wilayah, seperti Bengkulu, Lampung, Jambi, dan beberapa daerah lain di Provinsi Sumatra Selatan. Di wilayah migran, komunitas Semende cenderung mengelompok dengan tetap mempertahankan adat istiadatnya, khususnya adat tunggu tubang.

Migrasi yang dilakukan orang Semende adalah sebagai upaya untuk mencari kehidupan yang lebih baik. Hal ini terjadi karena pola pewarisan harta, seperti rumah dan lahan, lebih diprioritaskan untuk anak perempuan, khususnya anak perempuan tertua. Anak perempuan tertua (tunggu tubang) ditugaskan untuk mengelola dan memanfaatkan harta warisan tersebut untuk kepentingan keluarga luasnya. Oleh sebab itu, walaupun anak perempuan tertua mendapat prioritas untuk mewarisi harta orang tuanya, bukan berarti anak laki-laki dan anak perempuan lainnya tidak akan mendapatkan harta warisan. Apabila keluarga tersebut memiliki banyak harta, maka setelah anak perempuan mendapatkan warisan yang dianggap mencukupi, harta lainnya akan dibagi secara merata kepada anak laki-laki dan anak perempuan lainnya. Akan tetapi, bila harta yang dimiliki terbatas, biasanya semua harta akan diserahkan penguasaannya kepada anak perempuan tertua ini.

Keadaan di atas menunjukkan bahwa harta warisan tunggu tubang sebenarnya adalah harta milik bersama (apit jurai), yang penguasaannya

1 Disadur dari Buku Panduan Deklarasi Paguyuban Jurai Semende Nusantara dan Pemberian Gelar Kehormatan Adat Semende yang diadakan pada tanggal 21 Februari 2008 di Desa Pulau Panggung, Kecamatan Semende Darat Laut, Kabupaten Muara Enim. diserahkan pada anak perempuan tertua (tunggu tubang). Pemilik warisan ini sendiri adalah semua anggota keluarga tersebut yang dipimpin oleh anak laki-laki tertua (jenangtue), yang bertugas mengontrol pemanfaatan harta tersebut agar tetap sesuai dengan peruntukannya. Agar tidak terjadi konflik kepentingan di antara para anggota keluarga, saudara laki-laki ibu (meraje) diminta menjadi hakim yang akan mengadili keponakannya apabila tidak menjalankan fungsinya, baik sebagai tunggu tubang maupun sebagai jenang.

Pola pewarisan ini membawa konsekuensi bahwa sebagian besar anak laki-laki akhirnya tidak akan memiliki harta yang mencukupi untuk menghidupi keluarga nantinya. Kondisi ini "memaksa" anak laki-laki Semende harus pergi merantau ke daerah lain dengan tujuan mencari kehidupan yang lebih baik. Hal ini lah yang membuat terbentuknya kampung-kampung orang Semende di beberapa lokasi sekitar wilayah adat mereka di Muara Enim. Sebaran orang Semende ini tidak hanya dapat ditemui di berbagai wilayah yang ada di Provinsi Sumatra Selatan, tetapi juga ditemukan di beberapa wilayah yang ada di Provinsi Bengkulu, Lampung, dan Jambi. Bahkan menurut mitos yang diyakini orang Semende, sebaran komunitas mereka juga ditemukan di wilayah Banten.

Naim (1984) mengemukakan bahwa pola migrasi orang Semende sedikit berbeda dengan orang Minangkabau yang cenderung menyebar dan tidak terikat dengan pola pemukiman yang sama. Pola migrasi orang Semende cenderung akan mengelompok dan membentuk sebuah kampung yang sama. Pola mengelompok ini lebih disebabkan karena nilai budaya yang mengharuskan mereka untuk juga mampu menunjukkan keberhasilan mereka di daerah rantau. Salah satu wilayah perantauan orang Semende dapat ditemukan di Kecamatan Muara Sahung, Kabupaten Kaur, Provinsi Bengkulu. Orang Semende di Muara Sahung hidup mengelompok di tengah-tengah komunitas patrilineal yang sangat menekankan pola pewarisan kepada anak laki-laki. Perkenalan dengan budaya lain membuat adat tunggu tubang yang mereka terapkan dalam kehidupan cenderung mengalami intervensi budaya, yang memaksa mereka untuk 
melakukan adaptasi yaitu dengan cara melakukan redefinisi terhadap adat tunggu tubang itu sendiri.

Redefinisi dalam konteks ini dipahami sebagai mekanisme yang dilakukan komunitas migran Semende dengan cara mengonsepsi ulang pemahaman tentang adat tunggu tubang yang mereka miliki. Menurut Mellor \& Schiff (1975), proses redefenisi dilakukan oleh suatu komunitas sebagai bentuk mempertahankan pandangan mereka tentang diri dan identitasnya. Oleh sebab itu, proses redefinisi bukan berarti menghilangkan tunggu tubang sebagai identitas itu sendiri, tetapi lebih mendefinisikan kembali tunggu tubang tersebut sesuai dengan perkembangan kondisi yang dihadapi. Proses ini penting dilakukan komunitas migran Semende sebagai cara mempertahankan diri dan identitasnya dari pandangan luar yang cenderung tidak sesuai dengan kerangka pemahaman yang dimiliki komunitasnya. Hasilnya adalah sebuah konsepsi baru yang tetap berbasis pada pemahaman lama sehingga Stuar Hall (dalam Lan, 2006), menyebutnya sebagai old and new identity.

Tulisan ini didasarkan pada asumsi bahwa tunggu tubang adalah identitas penting bagi komunitas Semende sebagai pembeda dirinya dengan komunitas sekitarnya. Oleh sebab itu, menghilangkan tunggu tubang sama artinya menghilangkan identitas ke-Semende-an seseorang. Berbagai tulisan dan kajian menunjukkan bahwa arti penting tunggu tubang ini tidak hanya sekedar pola pewarisan harta, tetapi lebih dipandang sebagai adat Semende itu sendiri (Moyer, 1984; Alihanafiah, 2008). Sebagai adat, maka tunggu tubang cenderung menjadi aturan yang berpedoman pada bagaimana komunitas Semende dalam berkehidupan sehari-hari, baik di daerah asal (Praditama, Suntoro, \& Adha, 2013; Saputro \& Wirawan, 2013; Setiawan, 2013), maupun di daerah migran (Iskandar,2003; Setiawan \& Cecep, 2016).

Komunitas Semende bukanlah komunitas yang tertutup, apalagi dengan kebiasaan merantau yang dilakukan kaum laki-lakinya sehingga pengaruh budaya luar cenderung ikut memengaruhi perubahan pandangan komunitas Semende tentang adat tunggu tubang itu sendiri (Saputro \& Wirawan, 2013; Murdiati, Sriati, Alfitri, Muham- mad, \& Taqwa, 2018). Akan tetapi, perubahan pandangan tersebut cenderung dilihat sebagai sebuah penyimpangan (Guspitawaty, 2002), bukan sebagai proses redefinisi yang dilakukan komunitasnya terhadap intervensi budaya luar tersebut. Penting untuk memandang perubahan sebagai bagian dari proses redefinisi, terkait dengan upaya yang dilakukan komunitas Semende, untuk tetap mempertahankan adat tunggu tubang, di tengah intervensi budaya luar yang memengaruhinya. Berangkat dari pemikiran di atas, maka artikel ini mencoba menggambarkan bagaimana proses redefinisi adat tunggu tubang yang terjadi di komunitas Semende migran yang ada di Muara Sahung (Bengkulu), serta implikasinya pada penguasaan pola pewarisan harta tersebut.

\section{METODE PENELITIAN}

Penelitian ini dilakukan dengan menggunakan pendekatan kualitatif deskriptif yang berusaha memahami realitas secara keseluruhan. Menurut Denzin dan Yvonna (1994), metode kualitatif bertujuan memahami gejala yang ada tanpa pengukuran, sedangkan analitik deksriptif berusaha memahami kognitif komunitas Semende tentang berbagai masalah yang mereka hadapi dan hubungan sosial dengan masyarakat setempat.

Informasi diperoleh melalui wawancara dengan informan yang terdiri dari pemimpin tradisi dan orang Semende. Informan dipilih melalui teknik snowball dengan menggunakan panduan penelitian yang menyertai proses penelitian di lapangan. Teknik pengumpulan data dilakukan dengan menggabungkan metode wawancara dan observasi lapangan. Oleh karena itu, setiap wawancara yang dilakukan selalu dibandingkan validitasnya (periksa dan periksa kembali) melalui observasi. Di sisi lain, pengamatan partisipasi yang dilakukan akan dibandingkan validitasnya (periksa dan periksa kembali) melalui wawancara mendalam kepada beberapa informan. Melalui teknik tersebut, dapat diperoleh data yang mampu menjelaskan realita seperti yang diharapkan.

Analisis data dilakukan dalam beberapa tahap. Pertama, memahami struktur kognitif orang Semende melalui sumber referensi. Kedua, menemukan model kognitif komunitas Semende di lapangan, terkait dengan maknanya bagi diri 
mereka sendiri dan komunitas lain di sekitar mereka. Langkah terakhir adalah menghubungkan (hubungan) antara kognitif komunitas Semende dan realitas empiris yang ditemukan di lapangan

\section{TUNGGU TUBANG: ADAT SEMENDE}

Tubang adalah sebutan untuk sebatang bambu (dua atau tiga ruas) yang digantung secara memanjang di atas perapian tungku dapur yang berfungsi sebagai tempat penyimpanan bumbu dapur. Keberadaan tubang yang ada di dapur, membuat intensitas keberadaan dan fungsinya sering dilekatkan dengan perempuan. Oleh karena itu, tunggu tubang lebih sering dimaknai sebagai kegiatan menunggu tubang yang biasanya dilekatkan kepada perempuan yang banyak menghabiskan waktu di dapur, baik untuk memasak maupun melakukan aktivitas lainnya. Seorang informan mencoba memberikan penjelasannya akan arti tunggu tubang tersebut.

"Tubang itu adalah tempat bumbu masak yang digantung di dapur, jadi tunggu tubang itu artinya orang yang menunggu tubang. Biasanya yang menunggu tubang di dapur itu adalah perempuan, makanya tunggu tubang dilekatkan pada anak perempuan." (wawancara dengan Pak Husdin (Desa Muara Sahung, 23 April 2016)

Secara simbolis, tunggu tubang adalah sebutan pada seorang anak perempuan tertua dalam sebuah keluarga yang ditugasi menjaga, memelihara, dan memanfaatkan harta pusaka yang dimiliki oleh keluarga tersebut, meliputi rumah dan lahan pertanian yang ada (Setiawan, 2013; Iskandar, 2003; Guspitawaty, 2002). ${ }^{2}$

Harta tunggu tubang dalam bentuk rumah lebih difungsikan sebagai tempat berkumpul bagi anggota kerabat tunggu tubang dan tempat pulang bagi anggota keluarga yang pergi merantau. Di samping itu, rumah juga berfungsi sebagai tempat melakukan berbagai aktivitas upacara yang dilakukan keluarga tersebut. Sebagai rumah keluarga, seorang tunggu tubang berkewajiban untuk menjamu dan melayani kebutuhan seluruh saudaranya ketika berkumpul atau ketika

2 Oleh beberapa peneliti, pola pewarisan kepada anak perempuan dalam adat tunggu tubang ini akhirnya sering menimbulkan kecurigaan bahwa Semende adalah penganut sistem matrilineal sebagaimana halnya Minangkabau. Lihat juga Moyer (1984). melakukan upacara. Seorang informan mencoba menjelaskan fungsi rumah bagi orang Semende sebagai berikut.

"Rumah tunggu tubang itu fungsinya tempat mengadakan kegiatan adat bagi keluarga luasnya, tempat pengasuhan dan perawatan orang tua dan saudara-saudara yang sudah tua dan sakit, dan kalau ada saudara yang gagal di rantau, dia juga masih ada tempat pulang. Sebagai pemilik rumah, maka tugas tunggu tubanglah memenuhi kebutuhan mereka yang sedang ada di rumah tersebut." (wawancara dengan Ibu Srimianti (Desa Ulak Lebar, 26 April 2016)

Dengan kata lain, rumah akan menjadi identitas bagi sebuah keluarga, dan menjadi acuan bagi seseorang ketika ingin merujuk asalusulnya. Begitu juga dengan harta dalam bentuk lahan yang dikuasakan kepada seorang tunggu tubang, pemanfaatannya ditujukan untuk diri dan keluarganya serta untuk saudara-saudaranya apabila dibutuhkan. Oleh sebab itu, seorang tunggu tubang harus mengolah dan memanfaatkan lahan tersebut semaksimal mungkin agar hasilnya bisa menjadi sumber penghidupan bagi seluruh anggota keluarga luas nya.

Penjelasan di atas menunjukkan bahwa tunggu tubang adalah posisi (jabatan) yang dikuasakan kepada seorang anak perempuan dengan tugas mengelola harta warisan untuk kepentingan bersama. Bila saudara-saudaranya membutuhkan dana, tunggu tubang akan mengeluarkan hasil produksi lahan yang ada untuk kepentingan saudaranya tersebut. Bila saudaranya membutuhkan tempat tinggal dan perawatan, tunggu tubang juga lah yang harus menyediakan sebuah kamar atau tempat di salah satu bagian dari rumah tersebut untuk saudaranya dan menyediakan segala kebutuhannya. Di samping itu, seorang tunggu tubang juga berkewajiban untuk memelihara dan merawat orang tua yang masih hidup, serta menjaga dan membersihkan makamnya apabila mereka sudah meninggal. Oleh sebab itu, sebidang lahan yang diwariskan orang tua kepada dirinya terkadang tidak cukup untuk melaksanakan kewajiban-kewajiban tersebut sehingga seorang tunggu tubang terkadang harus mencari biaya tambahan, baik dengan cara menggarap lahannya sendiri maupun menyewa lahan orang lain, bahkan terkadang harus meminjam dana kepada orang lain. 
Agar tanggung jawab seorang tunggu tubang tetap berjalan secara baik dan tidak menyimpang dari adat, maka seluruh saudara laki-laki tunggu tubang (jenang) ${ }^{3}$ yang dipimpin oleh saudara lakilaki tertua (jenangtue), akan selalu mengontrol pemanfaatan harta warisan yang dilakukan tugas tunggu tubang. Agar keharmonisan keluarga ini tetap terjaga, saudara laki-laki ibu (meraje) akan selalu mengayomi, mengontrol, dan mengingatkan tunggu tubang dan saudara-saudaranya. Bahkan seorang meraje berhak untuk mengadili mereka apabila tidak menjalankan aturan adat yang ada. Munculnya tokoh jenang dan meraje di komunitas Semende ini tidak saja menunjukkan arti pentingnya kekuasaan bagi seorang laki-laki sebagai penjaga adat, tetapi juga menunjukkan arti pentingnya garis keturunan laki-laki (patrilineal) dalam komunitas ini.

Keberadaan tokoh jenang dan meraje dalam sistem tunggu tubang ini bukan berarti tidak memunculkan persoalan dalam komunitasnya. Pada banyak kasus, kekuasaan sebagai pengontrol sistem tunggu tubang sering disalahgunakan untuk mengambil manfaat dari harta warisan tersebut. Kondisi ini tidak saja disebabkan karena kuatnya intervensi budaya patrilineal dengan pola pewarisan kepada laki-laki yang ada di sekitarnya, tetapi juga karena menguatnya pengaruh Islam yang akhirnya dijadikan landasan dalam kehidupan (termasuk dalam sistem pewarisan). Di Muara Sahung, komunitas patrilineal yang ada di sekitarnya menempatkan kekuasaan dan penguasaan harta warisan kepada anak laki-laki. ${ }^{4}$ Akibatnya, komunitas patrilineal di sekitarnya sering memandang laki-laki Semende sebagai "laki-laki yang dikuasai perempuan". Berikut pendapat salah satu informan mengenai pendapat tersebut.

3 Di daerah asalnya atau di komunitas Semende di Muara Enim, saudara laki-laki tunggu tubang ini sering disebut juga dengan istilah lautan, dan tidak memiliki kekuasaan sebagaimana di daerah Muara Sahung ini. Sementara itu, istilah jenang lebih mengacu pada seorang laki-laki yang memiliki kekuasaan sehingga di Muara Enim, istilah jenang ini lebih dilekatkan pada kelompok meraje (saudara laki-laki ibu.)

4 Di Muara Sahung (Bengkulu), komunitas migran Semende ini hidup berdampingan dengan komunitas patrilineal seperti Rejang, Serawai, dan kelompok migran Besemah yang relatif kuat nilai patrilinealnya.

\begin{abstract}
"Pandangan ini biasanya diberikan pada laki-laki yang kawin dengan tunggu tubang dan lebih memanfaatkan lahan warisan tunggu tubang tersebut. Biasanya yang jadi suami tunggu tubang itu adalah laki-laki yang tidak berpunya, makanya pandangan ini sering muncul dari masyarakat lain.
\end{abstract}

Kalau saya lebih enak membeli dan mengolah lahan milik sendiri sendiri, bukan warisan dari orang tua. Jadi, kalau nanti mau diwariskan menjadi harta tunggu tubang lebih puas rasanya daripada mewarisi harta tunggu tubang itu sendiri." (wawancara dengan Pak Lihayrun (Desa Muara Sahung, 20 April 2016)

Citra yang dilekatkan pada laki-laki Semende ini sedikit banyak ikut memengaruhi upaya lakilaki untuk menguatkan kekuasaan dan perannya terhadap harta warisan tersebut. Masuk dan menguatnya nilai-nilai Islam di komunitas Semende semakin memberi legitimasi pada laki-laki untuk menguatkan posisi dirinya sebagai pemimpin. ${ }^{5}$ Nilai-nilai Islam yang menempatkan laki-laki sebagai pemimpin selalu diwacanakan dan menjadi dasar dalam menguatkan hak laki-laki sebagai pemilik kekuasaan dan penguasaan terhadap harta warisan (Murdiati, Sriati, Alfitri, Muhammad, \& Taqwa, 2018). Persoalannya, kekuasaan jenang dan meraje ini dianggap ada karena tetap adanya perempuan yang menempati posisi tunggu tubang. Dengan kata lain, kekuasaan laki-laki ada karena tunggu tubang dan tunggu tubang lestari karena adanya laki-laki yang menjalankan tugas sebagai pengontrol adat.

Munculnya sistem tunggu tubang sebagai bentuk pewarisan harta kepada anak perempuan ini tidak terlepas dari mitos nenek moyang mereka sebelumnya yang merasa tidak puas dengan pola kekuasaan patrilineal yang lebih didominasi oleh kelompok laki-laki. Mitos asal-usul mereka menjelaskan bahwa komunitas Semende berasal dari pecahan komunitas Basemah yang ada di Kabupaten Lahat, Sumatra Selatan yang sangat kuat nilai patrilinealnya, sebagaimana diceritakan informan berikut.

5 Menurut Buku Panduan Deklarasi Paguyuban Jurai Semende Nusantara dan Pemberian Gelar Kehormatan Adat Semende (2008), perubahan sosial yang terjadi di Semende diperkirakan sudah mulai terjadi sejak Islam berkembang di komunitas Semende pada abad-17 melalui tokohnya yang dikenal sebagai Puyang Awak, yang dipercaya berasal dari Minangkabau. 
"Pada suatu hari terjadilah pertengkaran antara dua saudara, yaitu anak laki-laki (anak lanang) dengan saudara perempuan (anak betine). Saudara perempuan ini tidak suka melihat melihat saudara laki-lakinya terlalu meraje (dominan seperti raja) sehingga saudara perempuannya ini tidak bisa berbuat banyak dalam keluarga apalagi dalam kehidupan sehari-hari."”6 (wawancara dengan Pak Musdin (Desa Ulak Lebar, 26 April 2016)

“... Anak betine ini lalu pergi dan membangun kampung sendiri di daerah baru, yang diberi nama Semende, yang berarti same (sama) dan ende (harga) yang bermakna 'semua harus dihargai secara sama." (wawancara dengan Pak Ali Budin (desa Ulak Bandung, 21 April 2016)

Mitos ini menjelaskan bahwa kepergian saudara perempuan ini disebabkan karena ketidaksetujuan saudara perempuan terhadap peran dan kekuasaan laki-laki yang begitu kuat. ${ }^{7}$ Kuatnya kekuasaan laki-laki ini membuat pola pewarisan lebih banyak diserahkan penguasaannya pada laki-laki, karena anak perempuan setelah menikah akan pergi dan menjadi bagian dari keluarga suaminya. Resistensi terhadap adat di daerah asal (Besemah) inilah yang kemudian melahirkan pola pewarisan yang dikenal sebagai tunggu tubang. Di komunitas Semende, pola pewarisan tunggu tubang kemudian dikuatkan sebagai identitas pembeda komunitasnya dengan daerah asal mereka di Besemah dan dengan komunitas lain di sekitarnya.

Sistem pewarisan tunggu tubang ini terus dijaga dan dikuatkan,walaupun mereka keluar dari wilayah adatnya dan terus bermigrasi ke berbagai wilayah. Terlepas, apakah mereka patrilineal atau matrilineal, secara ideal, apabila beban dan tanggung jawab tunggu tubang ini dilaksanakan dengan baik maka komunalitas sebuah keluarga akan terus terjaga. Dengan kata lain, ada kemungkinan tidak akan ada anggota keluarga yang akan termiskinkan apabila sistem adat tunggu tubang tetap terjaga dan berjalan

6 Ada kemungkinan, perkelahian antara dua saudara ini terkait dengan ketidaksetaraan penguasaan sumber daya dengan beban dan tugas yang diemban oleh masingmasing. Lihat juga Alihanafiah (2008).

7 Di komunitas Besemah, laki-laki diposisikan sebagai pemilik kekuasaan yang disebut sebagai punyimbang. Kuatnya posisi laki-laki ini juga tergambar dari arca-arca yang ditemukan para ahli arkeologi di Besemah. Lihat Triwurjani (2014). sesuai dengan aturan ideal tersebut. Persoalan sering muncul ketika seorang tunggu tubang, karena desakan kebutuhan yang banyak, akhirnya memanfaatkan harta warisan tersebut untuk kepentingan diri dan keluarganya saja. Di sisi lain, juga sering ditemukan saudara laki-laki tunggu tubang terkadang berharap akan mendapatkan manfaat yang lebih dari harta tunggu tubang yang diterimanya selama ini. Ketidakpuasan seperti inilah yang kemudian memunculkan konflik internal dalam keluarga yang membuat harta tunggu tubang akhirnya diambil alih oleh saudara laki-laki atau diperjualbelikan.

\section{HARTE DAN TUNGGUAN: IDENTITAS BARU ADAT SEMENDE}

Menurut Moyer (1984), komunitas Semende adalah salah satu komunitas yang suka berkelana (bermigrasi). Namun, berbeda dengan komunitas Minangkabau yang bermigrasi karena tekanan adat (Naim, 1984), migrasi yang dilakukan komunitas Semende lebih sebagai upaya untuk memperbaiki hidup yang lebih baik (Moyer, 1984). Hal ini disebabkan karena adat tunggu tubang yang diterapkan dalam komunitasnya membuat laki-laki relatif tidak memiliki kesempatan untuk menguasai harta warisan yang dimiliki orang tuanya. Satu-satunya cara adalah dengan membeli harta orang lain atau membuka lahan baru. Persoalannya, di daerah asal ada kecenderungan sebagian besar lahan adalah lahan tunggu tubang sehingga proses jual beli relatif sulit dilakukan. Kondisi inilah yang membuat banyak laki-laki Semende akhirnya mencari wilayah baru sebagai sumber kehidupannya. Oleh sebab itu, dengan mengandalkan keahlian mereka sebagai peladang dataran tinggi, arah migrasi orang Semende cenderung akan dilakukan ke wilayah perbukitan dengan cara membuka ladang-ladang baru atau mengolah ladang yang telah ada.

Kebiasaan ini membuat komunitas Semende akhirnya banyak melakukan migrasi ke berbagai wilayah yang ada di sekitarnya, seperti Bengkulu, Lampung, Jambi, dan beberapa daerah lain di Provinsi Sumatra Selatan. Di wilayah migran, komunitas Semende ini cenderung mengelompok dengan tetap mempertahankan adat istiadatnya, khususnya adat tunggu tubang. Akan tetapi, di 
Muara Sahung (Bengkulu), adat tunggu tubang cenderung telah mengalami proses redefinisi. Artinya, adat tunggu tubang tetap dijalankan dan diakui keberadaannya, tetapi aturan yang dijalankan sudah mengalami perubahan makna. Redefinisi terhadap adat tunggu tubang ini terjadi sebagai bentuk adaptasi yang dilakukan oleh komunitas dalam menyikapi intervensi budaya luar yang terus menyusup masuk dalam kehidupan masyarakatnya.

Secara ideal, penguasaan terhadap harta warisan diserahkan kepada anak perempuan tertua (tunggu tubang), sedangkan anak laki-laki (jenang) lebih diposisikan sebagai pengontrol agar tunggu tubang bisa melaksanakan amanah adat tersebut. Akan tetapi di Muara Sahung, otoritas terhadap harta warisan ini mulai mengalami degradasi, sebagaimana tergambarkan dalam tabel 1.

Tabel di atas menunjukkan bahwa telah terjadi pemindahan penguasaan terhadap lahan komunal, yang secara ideal ada dalam penguasaan tunggu tubang. Pemindahan penguasaan ini tidak terlepas dari konflik internal yang sering terjadi dalam keluarga luasnya, di mana tunggu tubang sering dituduh oleh jenang tidak mampu mengolah dan memanfaatkan lahan komunal tersebut untuk kepentingan keluarga luasnya. Tuduhan ini tidak semuanya benar, karena menurut tunggu tubang, luas lahan warisan yang dikuasakan kepada mereka relatif terbatas sehingga produksi yang dihasilkan sering tidak mencukupi untuk memenuhi tuntutan keluarga luasnya. Seorang tunggu tubang mencoba memberikan ilustrasi akan keterbatasan tersebut.

\footnotetext{
"Kalau saudara kita mau mengadakan upacara seperti menikahkan anaknya di rumah tunggu tubang, maka sudah jadi kewajiban tunggu tubang untuk memenuhi semua kebutuhan untuk upacara tersebut. Kalau jenang mau membantu tidak jadi
}

masalah, tetapi banyak kasus semua dibebankan pada tunggu tubang, dengan alasan mereka sudah diwarisi lahan keluarga tersebut." (wawancara dengan Ibu Muratia (Desa Ulak Bandung, 23 April 2016)

Kasus di atas menunjukkan bahwa tuntutan kepada seorang tunggu tubang dianggap tidak sebanding dengan luas dan produksi lahan yang mereka warisi. Sementara itu, tidak semua tunggu tubang memiliki lahan olahan lain kecuali lahan warisan tersebut sehingga seorang tunggu tubang terkadang hanya memanfaatkan lahan warisan tersebut untuk memenuhi kebutuhan keluarganya. Kondisi inilah yang sering memunculkan konflik antara tunggu tubang dengan jenang, yang sering menuduh tunggu tubang lebih memanfaatkan lahan warisan tersebut hanya untuk kebutuhan diri dan keluarganya saja, bukan untuk keluarga luasnya.

Dari sisi tunggu tubang, pemanfaatan lahan untuk diri dan keluarganya ini bukanlah sesuatu yang salah, karena secara adat, lahan warisan tersebut memang dimanfaatkan untuk dirinya dan untuk kepentingan keluarga luas apabila dibutuhkan. Sementara itu dari sisi jenang, terbatasnya lahan olahan dan sumber penghidupan lain juga sering menjadi pemicu keinginan mereka untuk juga ikut memanfaatkan lahan tunggu tubang tersebut, bahkan pada beberapa kasus juga berkeinginan untuk menguasainya. Munculnya berbagai konflik kepentingan terhadap lahan tunggu tubang ini membuat sebagian perempuan Semende di Muara Sahung mulai enggan untuk menjadi tunggu tubang. Bagi perempuan Semende di Muara Sahung, menjadi tunggu tubang dianggap bukan posisi yang menguntungkan, dan kalaupun mereka mau menerima posisi tersebut, ada kecenderungan karena "terpaksa" menerimanya dengan alasan untuk tetap menjaga dan memelihara orang tua, seperti diutarakan informan berikut.

Tabel 1. Pergeseran Pola Penguasaan Harta Warisan di Muara Sahung, Bengkulu

\begin{tabular}{lll} 
Karakteristik & Ideal normatif & Redefinisi \\
\hline Pola kepemimpinan dalam masyarakat & Meraje (saudara laki-laki ibu) & Meraje (saudara laki-laki ibu) \\
\hline Kepemilikan tanah komunal & $\begin{array}{l}\text { Penguasaan ada pada tunggu } \\
\text { tubang dan kontrol ada pada jenang }\end{array}$ & $\begin{array}{l}\text { Penguasaan dan kontrol ada pada } \\
\text { jenang }\end{array}$ \\
\hline Kepemilikan rumah komunal & $\begin{array}{l}\text { Penguasaan ada pada tunggu } \\
\text { tubang dan kontrol ada pada jenang }\end{array}$ & $\begin{array}{l}\text { Penguasaan ada pada tunggu tubang } \\
\text { dan kontrol ada pada jenang }\end{array}$ \\
\hline \hline
\end{tabular}


"Kalau saudara kita mau mengadakan upacara seperti menikahkan anaknya di rumah tunggu tubang, maka sudah jadi kewajiban tunggu tubang untuk memenuhi semua kebutuhan untuk upacara tersebut. Kalau jenang mau membantu tidak jadi masalah, tetapi banyak kasus semua dibebankan pada tunggu tubang, dengan alasan mereka sudah diwarisi lahan keluarga tersebut." (wawancara dengan Ibu Syamsami (Desa Ulak Lebar, 22 April 2016)

Kuatnya intervensi budaya patrilineal dari komunitas di sekitarnya, serta ketidakmampuan adat melindungi perempuan tunggu tubang dalam menjaga dan mempertahankan harta tunggu tubang, membuat laki-laki (jenang) seakan memiliki legitimasi untuk menguasai harta warisan keluarga yang seharusnya dikuasakan kepada tunggu tubang tersebut. Secara adat, jenang hanyalah pelindung agar harta warisan tersebut tetap terjaga dan berdaya guna bagi kepentingan keluarga luas. Akan tetapi sekarang, jenang dianggap sebagai posisi yang lebih menguntungkan karena "atas nama adat", jenang bisa menjadi penguasa harta warisan dan memperlakukan harta warisan tersebut sesuai dengan keinginan- nya (termasuk menjualnya). Redefenisi terhadap posisi jenang inilah yang membuat sebagian harta tunggu tubang sekarang beralih penguasaan kepada jenang. "Atas nama adat" pula, jenang mengambil alih kekuasaan dan penguasaan sumber daya ini dengan alasan karena banyak perempuan Semende di Muara Sahung tidak mau menjadi tunggu tubang.

Menurut adat Semende Muara Sahung, sebenarnya seorang laki-laki tidak bisa menjadi tunggu tubang, bahkan anak perempuan tengah pun juga tidak dibolehkan jadi tunggu tubang. Tunggu tubang hanya boleh dilekatkan pada anak perempuan tertua, dan apabila anak perempuan tertua tidak bisa atau tidak sanggup maka akan diberikan pada anak perempuan bungsu. Walaupun demikian, seorang laki-laki bisa saja menjadi tunggu tubang apabila memang tidak ada lagi perempuan dalam keluarga tersebut yang mau memegang posisi sebagai tunggu tubang. Oleh sebab itu, karena posisi tunggu tubang hanya dilekatkan kepada perempuan, maka lakilaki yang diposisikan sebagai tunggu tubang harus mendudukkan istrinya sebagai tunggu

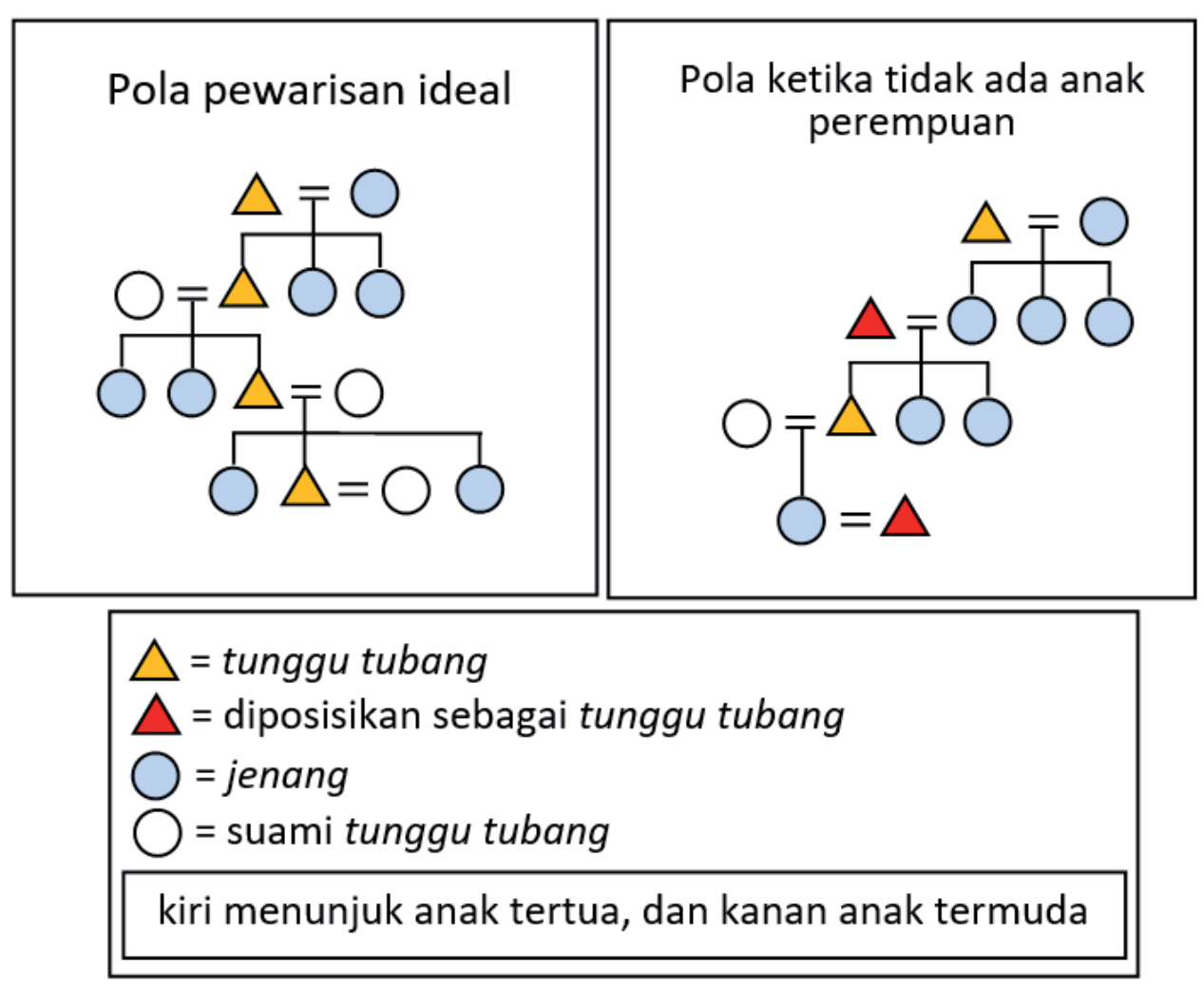

Gambar 1. Pola Pewarisan Harta Warisan Menurut Adat Semende 
tubang. ${ }^{8}$ Untuk selanjutnya, maka istri dari anak laki-laki tertua dari keluarga inilah yang nanti akan menduduki posisi tunggu tubang. Dengan kata lain, dalam ketentuan adat Semende di Muara Sahung, laki-laki sebenarnya tidak diposisikan sebagai tunggu tubang, tetapi posisinya telah ditetapkan sebagai jenang. Oleh sebab itu, ketika harta warisan dikuasai oleh jenang (melalui istrinya), maka tidak berlaku pada dirinya bahwa harta tersebut harus dikelola dan dipergunakan untuk kepentingan keluarga luasnya. ${ }^{9}$ Peruntukan akan harta warisan yang telah dikuasai oleh jenang tersebut akhirnya tergantung pada keputusan jenang itu sendiri.

Menguatnya kekuasaan jenang untuk menguasai harta warisan tunggu tubang akhirnya memunculkan paradoks. Di satu sisi, masyarakatnya tetap mencoba mempertahankan adat tunggu tubang sebagai identitas komunalnya, tetapi di sisi lain, penguasaan harta warisan mulai diambil alih oleh jenang. Dengan kata lain, adat tunggu tubang tetap dipertahankan dengan cara menyerahkan kekuasaan pada perempuan untuk menguasai rumah dan sebidang lahan. Akan tetapi, jenang memiliki hak menguasai lahan warisan lainnya. Kondisi inilah yang sedang menggejala di komunitas Semende di Muara Sahung, di mana harta warisan yang seharusnya dikuasai oleh tunggu tubang secara perlahan mulai diambil alih oleh jenang. Kondisi ini tidak saja melahirkan ketidakpercayaan sebagian masyarakat (khususnya kalangan muda) terhadap posisi jenang — apalagi meraje ${ }^{10}$ — tetapi juga memunculkan resistensi terhadap adat tunggu tubang itu sendiri.

8 Bila laki-laki yang akan diangkat menjadi tunggu tubang tersebut belum menikah, maka proses perkawinannya harus dilakukan dengan cara ngangkit, yaitu prosesi yang menempatkan istri sebagai calon tunggu tubang dalam keluarga suaminya tersebut.

9 Bila penguasaan harta warisan diberikan kepada tunggu tubang, maka secara adat memang diperuntukan bagi kepentingan bersama yang dikontrol oleh jenang. Namun, bila penguasaan harta warisan tersebut diserahkan kepada jenang, maka secara adat peruntukannya tidak lagi untuk kepentingan bersama.

10 Meraje (saudara laki-laki ibu) seharusnya menjadi penjaga akhir keutuhan harta warisan tunggu tubang, karena merajelah yang akan "menghukum" jenang apabila tidak menjalankan kontrol terhadap tunggu tubang, apalagi merebut dan menguasai harta tunggu tubang.
Resistensi terhadap adat tunggu tubang tidak serta merta menghilangkan keberadaan adat tunggu tubang itu sendiri, karena sebagian besar masyarakat masih membutuhkan adat tunggu tubang sebagai identitas yang membedakan mereka dengan komunitas lain di sekitarnya. Identitas tersebut ditunjukkan melalui pengakuan komunitas terhadap asal-usulnya, sebagaimana diutarakan informan berikut.

"Orang Semende itu tidak akan diakui sebagai bagian dari sebuah kampung, bila ia tidak mampu mampu menunjukkan dimana rumah tunggu tubang-nya. Sekurang-kurangnya seorang Semende harus mampu menunjukkan posisi tembokan (tanah tempat rumah tunggu tubangnya dulu berdiri). ${ }^{11}$ Itulah sebabnya mengapa adat tunggu tubang sejak dulu sampai sekarang masih penting dan masih dipertahankan." (wawancara dengan Pak Ceman (Desa Ulak Bandung, 20 April 2016)

Resistensi yang terjadi akhirnya melahirkan redefinisi terhadap adat tunggu tubang itu sendiri. Di Semende Muara Enim, jenang lebih diposisikan sebagai calon meraje yang mendampingi tunggu tubang dalam mengelolah harta warisna tersebut. Sementara itu, di Semende Muara Sahung, terjadi penguatan posisi jenang yang mulai ditempatkan sebagai meraje yang memiliki kekuasaan untuk mengendalikan dan mengambil alih harta warisan tunggu tubang tersebut.

Tidak berpihaknya adat dalam melindungi seorang perempuan tunggu tubang untuk menghalangi saudara laki-lakinya (jenang) untuk memperjualbelikan harta warisan sering dianggap sebagai rasa ketidakadilan sebagian perempuan Semende di Muara Sahung. Di satu sisi, mereka sering "dituduh" sebagai orang yang menguasai sendiri harta warisan keluarga, tetapi di lain sisi jenang "terkesan" diberi kesempatan untuk memperlakukan harta warisan tersebut secara semena-mena. Apalagi bila sudah dianggap "tertuduh", maka upat-cele (umpatan dan kutukan) akan dilekatkan kepada mereka, yang membuat mereka tidak saja akan disisihkan dalam keluarga, bahkan terkadang juga "dihakimi" oleh masyarakatnya.

11 Tembokan adalah istilah untuk menyebut tanah kosong yang diatasnya dulu pernah berdiri rumah yang dimiliki suatu keluarga. 
Redefinisi terhadap adat tunggu tubang terjadi dalam bentuk konseptualisasi, di mana terjadinya pembagian kekuasaan antara perempuan (tunggu tubang) dengan laki-laki (jenang) dalam hal penguasaan terhadap harta warisan tersebut. Harta tunggu tubang dalam bentuk rumah akhirnya lebih dikuasakan secara penuh kepada perempuan yang menjabat sebagai tunggu tubang, yang dalam komunitas Semende di Muara Sahung kemudian disebut sebagai tungguan. Sementara itu, warisan dalam bentuk lahan, yang kemudian mereka sebut sebagai harte, akan dibagi secara merata ke semua anggota keluarga, termasuk kepada perempuan yang menjabat sebagai tunggu tubang. Apabila harte dianggap sebagai warisan yang masih memungkinkan untuk dibagi-bagi (bahkan diperjualbelikan), maka tungguan lebih mengarah pada harta sebagai simbol keluarga sehingga hilangnya tungguan akan membuat simbol dan identitas juga dianggap akan hilang.

Proses redefinisi terhadap aturan adat ini mengingatkan kita kembali pada mitos terbentuknya komunitas Semende yang dahulu mencoba memisahkan diri dengan Basemah. Dalam mitos yang selalu dituturkan oleh masyarakat Semende, termasuk di Muara Sahung, dijelaskan bahwa perpisahan ini terjadi karena konflik internal antara saudara perempuan (anak betine) yang merasa diperlakukan tidak adil oleh saudara laki-lakinya (anak lanang). Adat yang dikembangkan di Basemah justru tidak berpihak kepada perempuan dan lebih memihak kepada laki-laki. Kondisi inilah yang melahirkan konflik di antara keduanya, yang memaksa saudara perempuan pindah dan mencoba memperbaiki ketentuan adat tersebut di daerah rantau (Muara Enim) sehingga melahirkan komunitas Basemah dengan identitas baru di daerah rantau, yang kemudian mereka sebut dengan Semende.

Mitos kepergian anak betine (anak perempuan) yang kemudian membangun wilayah baru ini di Muara Enim ini diyakini oleh masyarakat Semende di Muara Sahung sebagai dasar awal terbentuknya adat tunggu tubang. Mitos ini menunjukkan akan arti pentingnya adat tunggu tubang sebagai identitas komunitasnya di Muara Sahung, sebagaimana diutarakan oleh informan berikut.

\begin{abstract}
"Puyang betine (nenek moyang perempuan) pergi dan membangun daerah Semende itu, karena dia tidak suka dengan kepemimpinan puyang jantan (nenek moyang laki-laki) yang terlalu menguasai. Makanya puyang betine membangun Semende ini dulu, maksudnya jangan sampai kita sama juga dengan puyang jantan itu (baca adat Besemah)." (wawancara dengan Pak Ujang Busra (Desa Muara Sahung, 22 April 2016)
\end{abstract}

Oleh sebab itu, bagi sebagian orang Semende di Muara Sahung, tubang-tubang tidak saja sekedar pola kepemilikan lahan yang diberikan kepada anak perempuan tertua, tetapi juga bermakna sebagai alat penguat bagi kebertahanan masyarakat sebagai sebuah kelompok sosial. Sebagai identitas sosial, adat tunggu tubang tidak saja menempatkan arti pentingnya seorang perempuan sebagai pemegang dan penguasa harta warisan, tetapi juga memberi tempat bagi laki-laki sebagai penjaga keberlangsungan harta tunggu tubang tersebut. Seorang informan mencoba menjelaskan maksud mitos yang dipahaminya sebagai berikut.

“... rumah yang diberikan pada anak perempuan itu, bukan berarti milik dia (tunggu tubang) secara pribadi. Rumah itu tetap milik bersama (keluarga), tetapi diberi kuasa pada tunggu tubang untuk merawat dan memanfaatkannya." (wawancara dengan Pak Harsal (Desa Ulak Bandung, 20 April 2016)

“... maksud puyang (nenek moyang) dulu, perempuan itu diberi kekuasaan untuk mengurus dan memelihara rumah (dan harta benda keluarga) sehingga harta kita jadi terawat (lestari). Agar harta tetap terawat, maka disitulah laki-laki tertua (jenang) diminta untuk jadi pemimpin bagi adikadiknya supaya tidak bertengkar." (wawancara dengan Ibu Wariamak (Desa Ulak Lebar, 24 April 2016)

Bagi orang Semende di Muara Sahung, mitos asal usul mereka tidaklah menempatkan perempuan sebagai pemilik tunggal akan sumber daya tersebut. Akan selalu ada laki-laki yang menempati posisi tertentu dalam lingkaran adat tunggu tubang tersebut. Oleh sebab itu, menurut adat tunggu tubang bukan berarti kekuasaan ada di tangan perempuan (matriachat) dan bukan pula sebagai legitimasi bahwa Semende penganut keturunan perempuan (matrilineal). Sebaliknya, walaupun laki-laki diposisikan sebagai pemimpin 
kelompok yang memiliki kekuasaan penuh terhadap sumber daya yang ada (patriachat), tetapi tetap melegitimasi akan arti pentingnya perempuan dalam keluarga dan dalam kehidupan sosialnya. Dengan kata lain, adat tunggu tubang menempatkan laki-laki sebagai pelindung kelompok dan secara khusus pelindung kaum perempuan sebagai penerus keturunan. Secara sosial, pola adat demikian akhirnya menempatkan komunitasnya tetap bertahan karena terciptanya hubungan simbiosis antara saudara laki-laki dan saudara perempuannya.

Mitos ini cenderung tidak dikenali lagi oleh generasi muda, hanya sebagian generasi tua Semende Muara Sahung yang masih mengenalinya. Oleh karena itu, mitos ini akhirnya mulai kehilangan maknanya di tengah masyarakat di Muara Sahung. Namun di sisi lain, masyarakat Semende Muara Sahung tetap menyadari akan pentingnya adat tunggu tubang dalam kehidupan mereka, karena adat tunggu tubang inilah yang menjadi pembeda antara mereka dengan komunitas lain di sekitarnya. Pentingnya identitas bagi komunitas Semende di Muara Sahung ini membuat adat tunggu tubang akhirnya mengalami redefenisi makna. Adat tunggu tubang tidak lagi dilihat sebagai bentuk pengelolaan sumber daya demi keberlanjutan kehidupan komunalnya, tetapi lebih dilihat sebagai penguasaan sumber daya oleh perempuan.

Berangkat dari mitos yang ada, adat tunggu tubang telah menekankan bahwa perempuan tunggu tubang tidak bisa menjual harta warisan

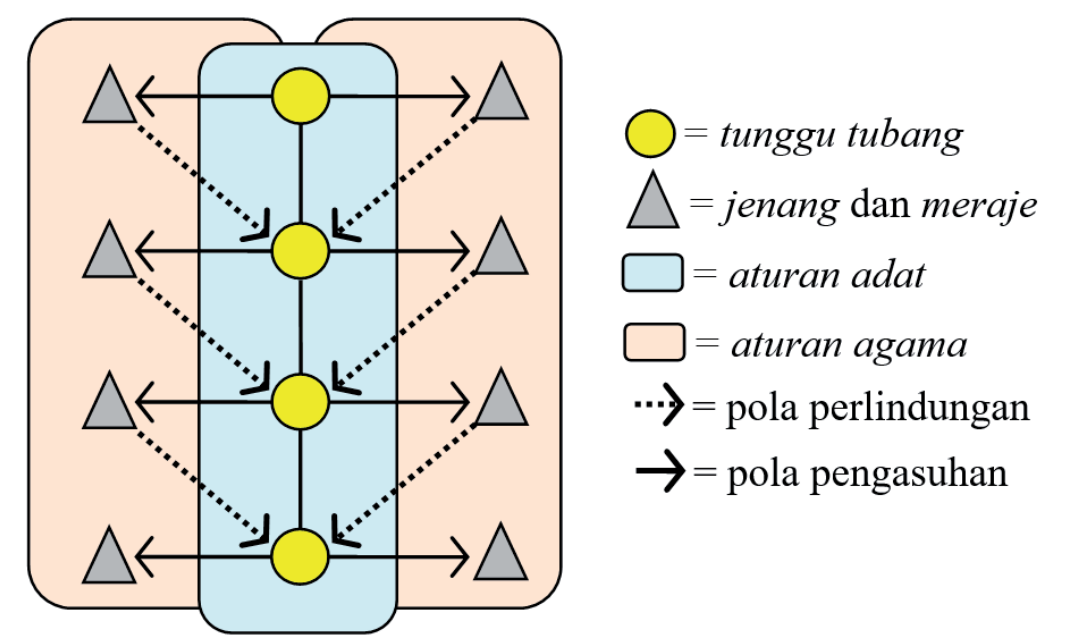

Gambar 2. Oposisi Binari antara Tunggu Tubang (Perempuan) dan Jenang (Laki-Laki) tersebut, karena hanya jenang yang memiliki kuasa untuk itu. Adat tunggu tubang hanyalah memberikan kuasa kepada perempuan untuk mengelola dan memanfaatkan sumber daya yang ada, sebagaimana dijelaskan informan berikut.

"Dari dulu tunggu tubang itu tugasnya memang
hanya menjaga dan merawat harta warisan agar
tetap bisa dimanfaatkan. Jenang juga gitu, dari
dulu dia sudah ditetapkan sebagai pemimpin
keluarga yang mengatur dan mengendalikan
semua urusan dalam keluarga, termasuk harta
warisan." (wawancara dengan Ibu Desi (Desa
Ulak Bandung, 24 April 2016)
"...sekarang anak perempuan tertua tetap dibilang
tunggu tubang, tapi hartanya sekarang hanya
dalam bentuk rumah (tungguan), sedangkan
tanah pertanian namanya harte dan sekarang tidak
lagi milik tunggu tubang, tetapi sudah beralih
ke jenang. Mau dipakainya atau mau dijualnya
bagaimana lagi, dia yang punya kuasa sekarang.
Kalau jenang kita baik, biasanya tunggu tubang
akan selalu dibantu kalau ada masalah, tapi kalau
dapatjenang yang jahat, mau apa lagi, karena baik
buruknya harte itu ada di tangan dia." (wawan-
cara dengan Ibu Titin (Desa Muara Sahung, 20
April 2016)

Penjelasan di atas menunjukkan bahwa redefinisi yang terjadi dalam pola pewarisan harta di komunitas migran Semende di Muara Sahung tidaklah menghapus keberadaan adat tunggu tubang itu sendiri. Peran dan posisi yang harus dimainkan antara tunggu tubang dan jenang juga tidak mengalami perubahan, tetapi dengan adanya redefinisi terjadi pengalihan otoritas penguasaan terhadap harta warisan itu sendiri,

$$
\begin{aligned}
& \bigcirc=\text { tunggu tubang } \\
& \triangle=\text { jenang dan meraje } \\
& \square=\text { aturan adat } \\
& \square=\text { aturan agama } \\
& \cdots \cdot=\text { pola perlindungan } \\
& \rightarrow=\text { pola pengasuhan }
\end{aligned}
$$


yang kemudian dilegitimasi melalui konsepsi baru yaitu harte (lahan pertanian) dan tungguan (rumah). Redefinisi ini sebenarnya mengisyaratkan kepada kita bahwa harta warisan akan tetap lestari selama jenang tetap memposisikan dirinya sebagai pengontrol agar tunggu tubang tetap mampu menjalankan amanah ditentukan adat secara adil. Akan tetapi, melalui redefinisi, adat tunggu tubang di Muara Sahung akhirnya lebih dilihat sebagai investasi yang bisa digunakan oleh semua anggota keluarga apabila dibutuhkan. ${ }^{12}$

\section{SIMPULAN}

Masyarakat Semende di Muara Sahung adalah salah satu kelompok Semende yang melakukan migran dari daerah asal yakni Muara Enim, Sumatera Selatan ke wilayah Bengkulu ini di masa lampau. Migrasi yang dilakukan oleh orang Semende ke Muara Sahung sedikit berbeda dengan migrasi yang dilakukan nenek moyang pendahulu mereka di Muara Enim. Migrasi awal yang dilakukan orang Semende dari Basemah ke Muara Enim lebih disebabkan oleh adanya konflik internal dalam kelompoknya di Basemah, yang diyakini karena munculnya pertikaian antara saudara laki-laki (anak lanang) dan saudara perempuan (anak betine). Pertikaian tersebut melahirkan komunitas yang dikenal dengan sebutan Semende, yang memunculkan identitas baru yang berbeda dengan daerah asal yaitu adat tunggu tubang.

Bagi komunitas Semende di Muara Sahung, tunggu tubang tidak saja dilihat sebagai aturan adat yang mengontrol pola hubungan dan interaksi sosial di antara mereka, tetapi juga sebagai identitas pembeda antara komunitasnya dengan komunitas yang ada di sekitarnya. Akan tetapi, karena kuatnya intervensi budaya yang mereka terima dari komunitas di sekitarnya, maka adat tunggu tubang tidak bisa dijalankan secara ideal sebagaimana yang diterapkan di daerah

12 Dalam ketentuan adat, sebenarnya harta warisan tunggu tubang bisa saja diperjualbelikan apabila memang kondisi sangat mendesak, seperti ketiadaan biaya untuk menghidupi orang tua, ketiadaan biaya untuk kesembuhan orang tua yang sedang sakit, dan ketiadaan biaya untuk menguburkan orang tua. Dengan kata lain, harta tunggu tubang memang akan dijual hanya untuk kepentingan orang tua bukan untuk kepentingan diri atau saudara-saudaranya. asal (Muara Enim). Di Muara Sahung, adat tunggu tubang, akhirnya mengalami redefinisi sebagai bentuk adaptasi budaya mereka terhadap lingkungan sosial yang dihadapi yang sangat menekankan pola pewarisan kepada laki-laki. Oleh sebab itu, sebagai identitas komunal, maka substansi dalam adat tunggu tubang tidak mengalami perubahan, tetapi peran dan posisi aktor yang ada di dalamnya mengalami penyesuaian.

Hal ini menunjukkan bahwa redefinisi terhadap adat (atau budaya secara umum), bukanlah sesuatu yang harus dianggap sebagai resistensi. Redefinisi haruslah dianggap sebagai bentuk adaptasi sebuah komunitas untuk tetap mempertahankan identitas dirinya di tengah kuatnya intervensi dan gempuran budaya luar. Melalui redefinisi, akhirnya adat tunggu tubang tetap terintegrasi dalam kehidupan komunitasnya, dalam bentuk disharmoni dalam keharmonisan. Dengan kata lain, pergeseran peran dan fungsi kekuasan yang terjadi dalam adat tunggu tubang di Muara Sahung, tidak saja telah mengatasi berbagai tekanan sosial, baik dalam bentuk intervensi budaya luar maupun keterbatasan sumber daya. Selain itu, adat tersebut juga semakin menguatkan identitas dan keberlangsungan masyarakat itu sendiri.

\section{UCAPAN TERIMA KASIH}

Artikel ini adalah hasil penelitian yang dilakukan oleh penulis pada tahun 2018 yang lalu. Untuk alasan ini, penulis ingin mengucapkan terima kasih kepada Kementerian Riset, Teknologi, dan Pendidikan Tinggi, Republik Indonesia atas penyediaan dana penelitian, yang dengannya data koleksi untuk artikel ini dimungkinkan. Penulis juga akan berterima kasih kepada Lembaga Penelitian dan Pengabdian Masyarakat Universitas Andalas (LPPM) atas dukungan mereka selama penelitian hingga artikel ini akhirnya diterbitkan. Akhirnya, terima kasih saya juga ditujukan kepada mahasiswa Antropologi FISIP Unand yang terlibat dalam proyek penelitian ini dan tim editor jurnal untuk kesempatan menulis dalam jurnal ini. 


\section{DAFTAR RUJUKAN}

Alihanafiah. (2008). Mengenal sepintas masyarakat hukum adat Semende. Jakarta: Pemda Tk.I Sumatera Selatan.

Denzin, N. K., dan Lincoln, Y. S. (Eds). (1994). Handbook of qualitative research. Thousand Oaks London-New Delhi: Sage Publications.

Guspitawaty, E. (2002). Penyimpangan sistem pewarisan yang terjadi pada masyarakat hukum adat Semendo Pulau Beringin Kabupaten OKU, Propinsi Sumatera Selatan [Tesis]. Magister Kenoktariatan, Universitas Diponegoro Semarang.

Iskandar. (2003). Kedudukan anak tunggu tubang dalam pewarisan masyarakat adat suku Semendo di Kota Palembang [Tesis]. Magister Kenoktariatan, Universitas Diponegoro Semarang.

Lan, T. J. (2006). Redefinisi etnisitas dalam konteks kebudayaan nasional. Jurnal Masyarakat dan Budaya, 8(1), 123-140.

Mattison, S. M. (2011). Evolutionary contributions to solving the matrilineal puzzle. Human Nature: An Interdisciplinary Biosocial Perspective, 22(1-2), 64-88.

Mellor, K., \& Schiff, E. (1975). Redefining. Transactional Analysis Bulletin, 5(3), 303-311.

Moyer, D. S. (1984). South Sumatra in the Indonesia field of anthropological study. Dalam de Josselin de Jong J. P. B. (Ed.), Unity in diversity, 88-99. Dordrecht-Holland: Foris Publication.
Murdiati, E., Sriati, Alfitri, Muhammad, \& Taqwa, R. (2018). The local wisdom of tunggu tubang culture in the challenges of the times (Study on ethnical Semende District Muara Enim South Sumatera). Makalah dipresentasikan dalam The 1st Sriwijaya International Conference on Environmental Issues 2018 (1st SRICOENV 2018), 26-27 September 2018. Palembang: Universitas Sriwijaya

Naim, M. (1984). Merantau: Pola migrasi suku Minangkabau. Yogyakarta: Gadjah Mada University Press.

Praditama, M. R, Suntoro, I., \& Adha, M. M. (2013). Sikap masyarakat terhadap adat tunggu tubang di Desa Pulau Panggung Kecamatan Semende Sarat Laut, Kabupaten Muara Enim. Journal Kultur Demokrasi, 1(5). Bandar Lampung : FKIP Universitas Lampung.

Saputro, A. R., \& Wirawan, B. (2013). Persepsi masyarakat Semende terhadap pembagian harta warisan dengan sistem tunggu tubang. Jurnal Sosiologi, 15(1), 51-62.

Setiawan, R. (2013). Status dan peranan tunggu tubang serta perubahannya pada masyarakat Semende Desa Muara Tenang Kecamatan Semende Darat Tengah Kabupaten Muara Enim [Skripsi]. Jurusan Sosiologi, FISIP Universitas Sriwijaya. Palembang.

Setiawan, H., \& Darmawan, C. (2016). Pelestarian adat Semende di Desa Ulu Danau, Provinsi Sumatera Selatan. Journal of Urban Society's Arts, 3(2), 57-63.

Triwurjani, Rr. (2014). Arca perempuan dan arca lakilaki pada kelompok arca megalitik Pasemah, Sumatera Selatan: Perpespektif gender. Jurnal Forum Arkeologi, 27(3), 35-46. 
